\title{
Designing a Framework for Training Teachers on Mobile Learning in Sub-Sahara Africa
}

\author{
Abimbade Oluwadara $^{1^{*}} \quad$ Bello Lukuman Kolapo ${ }^{2} \quad$ Ikechukwu Collins Esobi $^{3}$ \\ 1.Department of Science and Technology Education, University of Ibadan \\ Ibadan, Oyo State. Nigeria \\ 2.National Open University of Nigeria \\ Abuja, Nigeria \\ 3.Department of Food, Nutrition and Packaging Science \\ Clemson, South Carolina. USA
}

\begin{abstract}
Mobile technology has the potential to enhance the capabilities of students and educators in effective teaching and learning process. Understanding the factors that hinder integration of mobile technology in instructional delivery is key to the effective uptake of mobile technology for instructional purposes. The benefits of using mobile technology in the classroom can only be fully harnessed when teachers and other educational stakeholders are guided by framework that captures factors that enhance and hinder it use. It is against this background that this study seeks to design a framework for training teachers in the uptake of mobile learning in classrooms in SubSahara Africa. The interactions among the factors considered suggest that Personal and Societal beliefs, Ownership of devices, Cost of devices and Type of devices contribute significantly to the teachers' technology self-efficacy, mobile phone self-efficacy and readiness to use mobile learning for instruction. Training on pedagogy could also enhance uptake, likewise, technical, and instructional support need to be considered in content development, delivery and evaluation. Feedback constitutes an important variable throughout the process leading up to uptake. Therefore, these factors need to be properly considered in the uptake of mobile learning in classrooms in subSahara Africa. This would engender seamless integration of mobile learning in instructional delivery at different levels of education.
\end{abstract}

Keywords: Mobile learning, readiness, pre-service teachers training, mobile learning model, self-efficacy DOI: $10.7176 / \mathrm{JEP} / 11-32-07$

Publication date: November $30^{\text {th }} 2020$

\section{Introduction}

Technology has widened access and offered students all over the world especially from developing country opportunity to compete for good jobs. Summarily, 'technology has essentially leveled the global playing field' (Daggett, 2010). Learning technologies are changing teaching methods and the physical environment educators teach in, these changes will continue, and the classroom of the future will give room for learners exploration, and construction of 'internal models of understanding' (Education 2025, 2015). According to Donnell, (2015), the future of technology in education is in connectivity. He explained that the ability of various devices and people to connect inside and outside the classroom help teachers to teach more effectively.

Technology creates dynamic array of opportunity to plan, create, structure, organized and deliver lessons to the students. The affordances of mobile technologies provide teachers with such opportunity. The growth of the mobile industry in Sub Saharan Africa has made mobiles the core platform for the operation for many companies and $47 \%$ of companies in Sub-Sahara Africa (SSA) use mobile devices as part of their training and eLearning activities (Docebo, 2017). Many institutions prefer the use of mobile technology to create content and engage students with digital content and perform other administrative functions. Learning platforms are connected across cloud-based network, contextualize digital environment and there is on-the-go visibility of the learning progress of learners. Learners now have the understanding that their mobile devices could help them learn efficiently providing them with skills and knowledge on the spot and accumulated job-related experiences.

However, educators are quick to undertake mobile learning projects because of the explicit advantages found in journal articles without understanding its theoretical and pedagogical underpinnings (Abimbade, 2015), this might be the undoing of mobile learning. Telecommunication operators, vendors, and associated companies, as part of their corporate social responsibilities, create mobile learning projects devoid of the basic processes of instructional system design and excluding teachers in the development process. However, many of these mobile learning projects declare high level of success and new projects pattern their methodology around them - the cycle continues.

In many of the mobile phone-enabled projects, less time is devoted to training pre and in-service teachers on how to integrate mobile technologies into instruction; more emphasis is placed on how mobile learning platforms can be integrated into instructional. Examples include: MoMath, Jambmobile, UI-PHEA Mobile project, Dr Math and Quiz math (Adedoja and Abimbade, 2013; Shafika, 2012). Studies have documented that teachers need to be 
specifically trained in order to integrate Information and Communication Technology (ICT) in their teaching and that technology will have little effect unless teachers are adequately and appropriately trained (Markauskaite, 2007; Coley, Cradler, \& Engel, 2007). The training of teachers on how to use technology is a means to developing their technology and teaching skills to deliver effective instruction. McGrath (2009) indicates that having specific technology skills in teacher education training is a challenging task, and if we must prepare pre-service teachers for the future, considerable amount of effort must be put into developing their technology skills. For teachers, the skills acquired in using mobile technologies could help impact the research-based knowledge that exists concerning the best way to support students' learning. Learners in Africa expect teachers to use several different learning technologies effectively in the learning environment to help them in their learning (Fulkrum, 2005). In other words, training of teachers on the use of mobile technology underscores the importance for them to be competent in the use of learning technologies and enable them to draw on a variety of resources to make lessons interactive, motivating and useful for learners. With the exponential growth experienced in the mobile technology industry over the years especially in Africa and other developing countries, efforts are growing to use mobiles to train both pre and in-service teachers; who are in low supply compared to the large number of students they have to teach. The affordances of mobiles provide us with a platform for professional development (Adedoja and Abimbade, 2013).

Mobile learning is no longer at the infancy stage, there are enough information from research for the past two decades for educators. Administrators and policy makers know what have been wrongly done and how to mitigate the challenges. The dynamics in education have placed a lot of pressure on schools to improve learning outcomes of learners, make them adapt to complex nature of the world and learn to solve societal problems, among others. The schools in turn place huge demands on teachers, they are required to learn new roles and ways of teaching. Therefore, professional development is pivotal to enhancing the quality of teaching and learning in schools.

Africa has largely been left behind in designing a context-specific framework that suits the practical needs, socio-cultural, pedagogical demands and training of pre and in-service teachers in the uptake and use of mobile technologies for instructional purposes. Many institutions design their training approach based on frameworks adopted from America and OECD countries (UI DL Mobile Class, School OnThe Air, UX Mobile). The difference in socio-cultural context, infrastructure and pedagogical realities inform the need for a unique framework for the uptake and training on mobile learning in Africa. A search through databases show numerous journal articles, web postings and position papers on implementation strategies for mobile learning, innovative mobile content strategies, mobile learning instructional design, acceptance of mobile learning, evaluation patterns using mobiles, creation of native and mobile applications for learning and others. Many current studies continue to design and create elaborate ideas on how mobiles can be implemented for different category of users: farmers, administrators, students, teachers and others without much attention to the combination of institutional, pedagogical, personal factors that could affect the uptake of mobile learning by teachers (Adedoja and Abimbade, 2016).

FRAME (Framework for the Rational Analysis of Mobile Education) places emphasis on the learning and social activities of learners to accept mobile learning. The framework is devoid of the pedagogical needs of teachers who are the primary implementers of mobile learning. FRAME failed to address some external factors that could affect the uptake of mobile learning by administrators, learners and teachers. Also, Mobile Design: M learning Reference Model was able to use a practical research approach (Design Based Research) to analyse 'the motivational, contextual, pedagogical and performance support aspect of mobile learning' (Berking \& Haag 2015). Though the model leveraged on the robust nature of DBR, there is still no clear approach to the factors to be considered in training implementers on the uptake of mobile learning. However, this present study incorporated 'performance support and design strategy' component of the study to design the interactions among the variables such as the readiness of teachers, pedagogy, content and technical scaffold activities and other internal/external factors. Keegan (2003), endeavoured to explain how mobile learning can be incorporated into education and training. This study focused on the affordances of mobiles carried out in different studies. Mobile learning: A framework and evaluation discusses how eLearning dovetails into mobile learning focused more on activities in the classroom and alienate the various factors that could impact teacher's uptake and use of mobiles for instruction. In the study, towards a model for m-learning in Africa, Brown, (2005), explored different implementation patterns of mobile learning in Africa and proposed a model for the implementation of mobile learning in higher education, however, this proposed model is largely still untested. Other projects especially in Africa that address mobile learning implementation focus more on: profitability of mobile applications; designing of content are devoid of pedagogy, they focus on aesthetics and alienate teachers in content design and development (Abimbade, 2015).

The approaches for mobile learning training, uptake and use do not incorporate the infrastructural deficiencies of many schools and the society into models for training and practice. However, this model under consideration is grounded in the socio-cultural paradigm of Africa, and taking into cognizance the interaction among factors that affect the training, uptake and use of mobile learning by teachers. Teachers will generally oppose the uptake of a technology if the environment is not suitable for its use including technical support and training. Adedoja \& Abimbade, (2015) considered some factors that could affect the uptake of mobile learning especially in public 
schools in Nigeria.

- There are very large classes: The teachers have students as many as 200 to teach in a single class- planning, responding to questions and queries from students and sending learning objects to students could consume a lot of time they cannot afford.

- Teachers do not have the requisite skills, training to embark on mobile learning instruction

- Mistrust between teachers and students and teachers and parents such that parents are reluctant to allow teachers contact (be it SMS, or Email) their wards beyond school hours.

- Lack of interest by older teachers to use mobile phones for instruction

- Teachers feel students will abuse the opportunity to use the device, they fear students will use it to cheat during examinations, watching and sharing videos and listen music during school and lecture hours, cyber bullying and others.

- Teachers are concerned that they will not be able to control the language of expression most especially because interactions are done virtually, this they fear could engender indiscipline.

All the challenges culminate into a bias against the use of mobile phones for instruction in secondary schools and have made school administrators to sometimes place outright ban on students using it in the school premises. Francis (2008), highlighting the demerits of using mobile technology in schools, indicated that some students in Nigerian Secondary Schools use mobile phone to cheat during examination. Likewise, Rosen, Lim, Carrier, and Cheever (2011) expressed their concern that students' texting in the classroom can be a form of distraction to the students and other colleagues in the classroom. Also, Ojerinde, (2011) also commented on the issue of students using mobile phones to cheat, he indicated that some Nigerian students smuggle phones into the examination venue with the purpose of using them to cheat. In the same vein, students send photos with sexual content to themselves through mobile phone and this often led to sexual harassment and cyberbullying in and outside the school premises (Seigle, 2010). There are also concerns that mobile phones could be a source of disruption in the class, these disruptions could be drug and gang related, sexting, cyberbullying and ringing causing distraction in the class (Lenhart, 2010).

Other factors have contributed to the uptake of mobile technologies in education in SSA include the liberalization of the sector leading to many mobile network providers to expand their services, more affordable mobile devices and internet services, localization of services to suit urban-rural users (PEW Research Centre, 2016). The uptake of mobile services especially by adolescent and school age individuals will largely drive subscriber growth in the future: it is already happening because $81 \%$ of the millennials indicated that their smartphones never leave their side (Docebo, 2017). The low cost of mobile devices has particularly increased ownership of cellphones, smartphones, tablets and other mobile devices. According to GSMA (2016), in 2016, there are 200 million smartphone connections in SSA. Individuals own their personal device because there is a growing market for used or secondhand devices, increase in the uptake of broadband services, and simple payment plan for devices and internet (Ericsson, 2016). Also, Asian manufacturers such as Tecno, Huwei, Gionee and others partner with local companies to set up assembling plants in SSA, this have considerably driven down the cost of smartphones and increased ownership (GSMA, 2016). Docebo, 2017, reported that between 2015 and 2016, the sale of smartphones jumped to 1.5 billion worldwide. This surge could slow over the next 5 years because of economic factors, income levels user happiness with their existing devices.

Growing competition for mobile market has also driven down the cost of mobile devices, some smartphones are sold as low as \$25. PEW Research Centre, (2015), indicated that $27 \%$ of the population in SSA use smartphones. $55 \%$ use cellphone and 10\% do not own any device. Ericsson, 2016, also reported that the largest mobile market in SSA has 2 smartphones retailing below \$50 making cellphones, smartphones, mobile broadband services more affordable and available and 400 million use basic/cellphone in SSA.

Implication for practice especially in SSA is that education has made gains from the growth of the mobile industry. More teachers and students own their devices, some schools acquire devices to use only the schools, mobiles can be used to create, manage, deliver digital content and evaluate students. Low cost of mobile devices is the major contributor to ownership of devices likewise, content have been adapted to suit the type of mobile devices students and teachers use. Students and teachers with limited internet access or connection, WIFI or cellphone (low end/mid end phones) or live in rural areas could use Short messaging Service (SMS) to deliver and manage instruction.

In SSA, challenges remaining connecting mobile network with rural areas where $60 \%$ of people live (GSMA, 2016). Students are constrained to use mobiles because of the deep poverty situation, low income which affect their purchasing power, poor supply of electricity and infrastructure. It takes more money to maintain mobile support services or structures in the rural areas than in the urban areas, therefore, it makes economic sense for mobile companies to focus on areas where they have high demand for their services which is in the urban areas. This create a huge digital divide between students who live in the rural or urban areas. Another major challenge is the social and political instability in some SSA countries (Abimbade, 2015).

Despite the apparent potential that mobile learning holds for promoting autonomy and improving learning, 
possibilities exist too for teachers' discomfort. Some could feel anxious or have little experience in the use of mobile devices in teaching. They may also have inadequate procedural knowledge about using mobile phones for instructional purpose. Efficacy is the ability to produce an effect, usually a specifically desired effect. Self-efficacy, then, is the perception of one's ability to produce an effect. Measuring self-efficacy can allow us to better predict behavioural outcomes, including attributes such as influence on choices, thought patterns, effort, resilience, emotional reactions and perseverance (Bandura, 1997).

Technology self-efficacy refers to the beliefs in one's capability to organise and use appropriate technological tools to attain stated objectives in teaching and learning (Hsu and Chiu, 2004). Sequel to this, if the beliefs of the pre-service / in service teachers are low to confidently use the mobile phone for instruction, it could in turn affect their disposition and ability to use it. Also, the use and non-use of mobile phone could be associated with their self-efficacy towards the device. Mobile phone self-efficacy is the personal beliefs in an individual's ability to carry out a given task on mobile devices. It is identified as a significant factor influencing individual's decisions to use mobile technology, and it also indicates the level of confidence in performing a task using mobile devices (Attewell, Savill-Smith and Douch, 2009). In terms of skills, it is important to acknowledge that teachers develop their skills in using mobiles in the classroom when they see the need to do so and would, often, reject it use if they perceive it difficult. They also would also embrace the use of mobiles if they see that it provides authentic solution to instructional problems and students learning (Abimbade, 2015). The feeling that mobile learning offers major benefit over existing learning methods and familiarity with the device is another factor that could have contributed to mobile phone self-efficacy (Adedoja, 2015).

Nature of delivery in Africa context should accommodate delivery with limited use of internet connection because about $60 \%$ of the learners have basic/low end or mid end phones, poor internet connectivity in the rural area where many of the students reside. Fakayode, (2017), indicated that multimedia content can be syndicated using SD card/memory cards and Bluetooth, textual information through SMS and compressed media through Multimedia Message Service (MMS). Activities presented to the learners are real-situated tasks which concretely relate to and solve problematic situation in the society.

Arguably, the most critical element in mobile technology use is the preparedness (Noeth and Volkov, 2004). Mobile Technology is an enabler and the preparedness of educators to use it could create a positive attitude toward its use in the classroom. Similarly, readiness to use a mobile technology is directly related to the positive attitude towards the use of the technology. However, many African teachers are apprehensive to use new digital technologies because of fear of failure and that technology would be their surrogate and eventual replace them. Readiness to use technology is one of the factors sine qua non to the uptake and the actual use of a particular technology (Wagner, 2005). Readiness to use a technology can contribute to the achievement of the instructional goal in the classroom. Hallikainen \& Laukkanen (2016). developed four parameters to measure readiness which include optimism, discomfort, innovativeness and insecurity. These parameters provide insight into effectively predict the preparedness of teachers to use technology in the classroom. Teachers are ready to use technology if they believe they will receive prompt and adequate support in using the technology for instruction.

The present study seeks to consider these ranking factors to design a framework for training teachers in the uptake of mobile technology for instructional purposes.

\subsection{Objectives of the study}

Objective of this study is to design a framework that is culturally relevant to the effective uptake and integration of mobile technologies into the instructional process in sub-Sahara Africa classroom, considering ranking variables and factors affecting the use of mobiles for instruction

\subsection{Research Questions}

1. What are the relationships between factors considered to affect the uptake of mobile technologies for instruction in SSA classroom?

2. How can a SSA context and culturally relevant framework be designed for the uptake of mobile learning?

\section{Methodology}

\subsection{Research design}

This study is an ex post facto research. Thus, there is no manipulation of variables, meaning of actions are got from specific questions asked. The researcher simply seeks Examine the interactions of the variables that may influence teacher's uptake of mobile learning. The researcher did not manipulate any variable, but deductions are made based on evidence collected.

\subsection{Sample Population and sampling technique}

One hundred and fifty Teachers (150) were purposively selected based on the teaching experience, willingness to participate in the study, access to technology especially computer and mobile devices. 
Instruments and procedure for data collection

The Instruments used are: Questionnaire on teachers' level of readiness to use mobile technologies in instruction; questionnaire on pedagogy training. The questionnaires were distributed among 150 respondents (teachers). Only one questionnaire was given to each respondent.

\subsection{Method of data analysis}

Data collected were analyzed using descriptive and inferential statistics. In descriptive statistics, frequency count, percentages, standard deviation and mean score were used to analyse the demographical information of the participants. The qualitative report was acquired using Focus group Discussion (FGD).

\subsection{Results}

3.1.1 Data Analysis

Table 1: Result of teachers' level of readiness

\begin{tabular}{|r|l|l|l|l|l|l|l|}
\hline S/NO. & \multicolumn{1}{|l|}{ SA } & $\mathbf{A}$ & $\mathbf{D}$ & $\mathbf{S D}$ & $\mathbf{M E A N}$ & $\begin{array}{l}\text { STD. } \\
\text { DEV }\end{array}$ \\
\hline 1. & $\begin{array}{l}\text { I am prepared to use mobile devices for } \\
\text { teaching }\end{array}$ & $80.5 \%$ & $17.0 \%$ & $1.6 \%$ & $.9 \%$ & 3.90 & 1.00 \\
\hline 2. & $\begin{array}{l}\text { Using mobile technologies to teach will } \\
\text { make me a better teacher }\end{array}$ & $56.7 \%$ & $18 \%$ & $14.7 \%$ & $6.7 \%$ & 2.16 & 1.00 \\
\hline 3. & $\begin{array}{l}\text { I want to develop my skills in using mobile } \\
\text { technologies for teaching }\end{array}$ & $78.1 \%$ & $21 \%$ & & $.9 \%$ & 3.63 & 1.00 \\
\hline 4. & $\begin{array}{l}\text { Teachers now know that using mobile } \\
\text { technologies in the class can improve } \\
\text { learning }\end{array}$ & $71.3 \%$ & $25.3 \%$ & $2.4 \%$ & $.9 \%$ & 3.71 & 1.00 \\
\hline 5. & $\begin{array}{l}\text { I want to know more about mobile learning } \\
\text { I am willing to give my students assignments } \\
\text { on mobile devices }\end{array}$ & $78.3 \%$ & $19.2 \%$ & $.8 \%$ & $1.7 \%$ & 3.55 & 1.00 \\
\hline 7. & $\begin{array}{l}\text { I will like to use mobile devices to teach in } \\
\text { my current class }\end{array}$ & $70.5 \%$ & $28.8 \%$ & $.8 \%$ & $7 \%$ & 3.76 & 1.00 \\
\hline 8. & $\begin{array}{l}\text { Students can learn better using mobile } \\
\text { technologies }\end{array}$ & $27.7 \%$ & $71.8 \%$ & $1.7 \%$ & $.8 \%$ & 3.18 & 1.00 \\
\hline
\end{tabular}

With the weighted average of 3.36, the result shows that teachers in Sub Sahara Africa have high level of readiness to use mobile learning for instructional delivery. This implies that teachers acknowledge the affordances provided by mobile learning and are ready to use this powerful technology to engage learners in classroom activities. For instance, $97.5 \%$ of the teachers are prepared to use mobile devices to facilitate teaching-learning process.

Table 2: What is the relative influence of teachers' Personal \& Societal beliefs, Ownership of devices, Cost of devices and Type of devices on teachers' readiness to mobile learning?

\begin{tabular}{|l|l|l|l|l|l|l|}
\hline \multirow{2}{*}{ Model } & \multicolumn{2}{l}{$\begin{array}{l}\text { Unstandardized } \\
\text { Coefficients }\end{array}$} & $\begin{array}{l}\text { Standardized } \\
\text { Coefficients }\end{array}$ & T & Sig & Decision \\
\cline { 2 - 7 } & B & Std Error & Beta & & & \\
\hline (Constant) & 31.011 & 2.599 & & 10.762 & .000 & \\
\hline $\begin{array}{l}\text { Personal \& Societal } \\
\text { beliefs }\end{array}$ & 1543 & 297 & 055 & 645 & .000 & $*$ \\
\hline Ownership of devices & -1148 & 257 & -398 & -3998 & .000 & $*$ \\
\hline Cost of devices & 2963 & .698 & .329 & 3856 & .000 & $*$ \\
\hline Type of devices & 2245 & 245 & .312 & 3567 & .000 & \\
\hline
\end{tabular}

$*=$ significant at $\mathrm{p}<0.05$

Table 2 depicts the relative influence of Personal \& Societal beliefs, Ownership of devices, Cost of devices and Type of devices to predict teacher's readiness. The analysis shows that Personal \& Societal beliefs, Ownership of devices, Cost of devices and Type of devices all contribute to the prediction of teacher's readiness towards uptake of mobile devices for instruction. 
Table 3: What is the relative influence of teachers' Personal \& Societal beliefs, Ownership of devices, Cost of devices and Type of devices on teachers' mobile phone self-efficacy to mobile learning?

\begin{tabular}{|l|l|l|l|l|l|l|}
\hline \multirow{2}{*}{ Model } & \multicolumn{2}{|l|}{$\begin{array}{l}\text { Unstandardized } \\
\text { Coefficients }\end{array}$} & $\begin{array}{l}\text { Standardized } \\
\text { Coefficients }\end{array}$ & T & Sig & Decision \\
\cline { 2 - 8 } & B & Std Error & Beta & & & \\
\hline (Constant) & 30.633 & 2.543 & & 12.112 & .000 & \\
\hline Personal \& Societal beliefs & 645 & 864 & 076 & 611 & .000 & $*$ \\
\hline Ownership of devices & -1122 & 271 & -347 & -3988 & .000 & $*$ \\
\hline Cost of devices & 2899 & .698 & .397 & 3876 & .000 & $*$ \\
\hline Type of devices & 2800 & .660 & .290 & 2960 & .000 & \\
\hline
\end{tabular}

In Table 3 the standard regression weight (B), Standard Error of Estimate, Beta, T-ratio and the level of significance for Personal \& Societal beliefs, Ownership of devices, Cost of devices and Type of devices are calculated. The analysis shows that Personal \& Societal beliefs, Ownership of devices, Cost of devices and Type of devices predict the mobile phone self-efficacy of teachers.

Table 4: What is the relative influence of teachers' Personal \& Societal beliefs, Ownership of devices, Cost of devices and Type of devices on teachers' technology self-efficacy to mobile learning?

\begin{tabular}{|l|l|l|l|l|l|l|}
\hline \multirow{2}{*}{ Model } & \multicolumn{2}{|l|}{ Unstandardized Coefficients } & $\begin{array}{l}\text { Standardized } \\
\text { Coefficients }\end{array}$ & T & Sig & Decision \\
\cline { 2 - 7 } & B & Std Error & Beta & & & \\
\hline (Constant) & 31.723 & 2.709 & & 12.003 & .000 & \\
\hline Personal \& Societal beliefs & 598 & 974 & 078 & 689 & .000 & $*$ \\
\hline Ownership of devices & -1178 & 254 & -345 & -4201 & .000 & $*$ \\
\hline Cost of devices & 2876 & .767 & .345 & 3890 & .000 & $*$ \\
\hline Type of devices & 2097 & .801 & .298 & 3561 & .000 & $*$ \\
\hline
\end{tabular}

Table 4 depicts the relative contribution of each of the independent variables on the dependent variable in the study. The contributions of Personal \& Societal beliefs, Ownership of devices, Cost of devices and Type of devices on teachers' technology self-efficacy to mobile learning are all significant. From the values of the Beta weights, Personal \& Societal beliefs contributed 7.8\%, Ownership of devices 34.5\%, Cost of devices 34.5\% and Type of devices $29.8 \%$. This indicates that all the factors contribute significantly to the teachers' technology self-efficacy to mobile learning.

Table 5: Training on Pedagogy

\begin{tabular}{|c|c|c|c|c|c|c|c|}
\hline S/NO. & & SA & $\mathbf{A}$ & D & SD & MEAN & $\begin{array}{l}\text { STD. } \\
\text { DEV }\end{array}$ \\
\hline 1. & $\begin{array}{l}\text { I can support various student learning styles } \\
\text { with mobile learning }\end{array}$ & $62.5 \%$ & $20.8 \%$ & $10 \%$ & $6.7 \%$ & 2.14 & 1.00 \\
\hline 2 & $\begin{array}{l}\text { I can use mobile technologies to prepare my } \\
\text { lesson }\end{array}$ & $55.8 \%$ & $21.9 \%$ & $10 \%$ & $11.5 \%$ & 2.54 & 1.00 \\
\hline 3. & $\begin{array}{l}\text { I can use mobiles to track my students } \\
\text { learning progress }\end{array}$ & $68.3 \%$ & $9.2 \%$ & $14.2 \%$ & $7.5 \%$ & 2.08 & 1.00 \\
\hline 4. & $\begin{array}{l}\text { Finding digital learning resources is easy } \\
\text { using mobile technologies }\end{array}$ & $37.5 \%$ & $56.7 \%$ & $4.2 \%$ & $2.7 \%$ & 2.17 & 1.00 \\
\hline 5 & $\begin{array}{l}\text { I use mobile technologies to facilitate } \\
\text { teaching specific concepts }\end{array}$ & $45 \%$ & $44.2 \%$ & $1.7 \%$ & $9.2 \%$ & 2.60 & 1.00 \\
\hline 6 & $\begin{array}{l}\text { I can use mobiles to send digital learning } \\
\text { resources to my students }\end{array}$ & $35.8 \%$ & $50 \%$ & $6.7 \%$ & $7.5 \%$ & 2.27 & 1.00 \\
\hline 7 & $\begin{array}{l}\text { I can facilitate teaching pupils with } \\
\text { disabilities with mobiles }\end{array}$ & $8 \%$ & $82.5 \%$ & $10 \%$ & $6.7 \%$ & 2.94 & 1.00 \\
\hline 8 & $\begin{array}{l}\text { I have basic understanding of mobile } \\
\text { learning }\end{array}$ & $45.8 \%$ & $31.7 \%$ & $10 \%$ & $11.7 \%$ & 2.63 & 1.00 \\
\hline 9 & $\begin{array}{l}\text { I can support activities that facilitate higher } \\
\text { order thinking using mobile technologies }\end{array}$ & $56.7 \%$ & $18 \%$ & $14.7 \%$ & $6.7 \%$ & 2.16 & 1.00 \\
\hline 10 & $\begin{array}{l}\text { Mobile learning can support creativity in my } \\
\text { students }\end{array}$ & $68.1 \%$ & $21 \%$ & $10 \%$ & $.9 \%$ & 3.63 & 1.00 \\
\hline 11 & $\begin{array}{l}\text { I can create authentic activities for my } \\
\text { students using mobile technologies }\end{array}$ & $50 \%$ & $37.2 \%$ & $10.3 \%$ & $2.2 \%$ & 3.12 & 1.00 \\
\hline 12 & Evaluation & $25.0 \%$ & $60.8 \%$ & $12.5 \%$ & $1.7 \%$ & 2.39 & 1.00 \\
\hline & Weighted average & & & & & 2.66 & \\
\hline
\end{tabular}

Weighted average $72 \%$ 
Table 5 depicts teachers' competence on pedagogic use of mobile learning to support classroom instruction. With the weighted average of $72 \%$, the result indicates that teachers possess the basic skills and competence to integrate mobile learning into instructional delivery. For instance, $83.3 \%$ of the teachers can support various student learning styles with mobile learning. Also, $87.2 \%$ of the teachers are competent to create authentic activities for students using mobile technologies.

\subsection{Discussion}

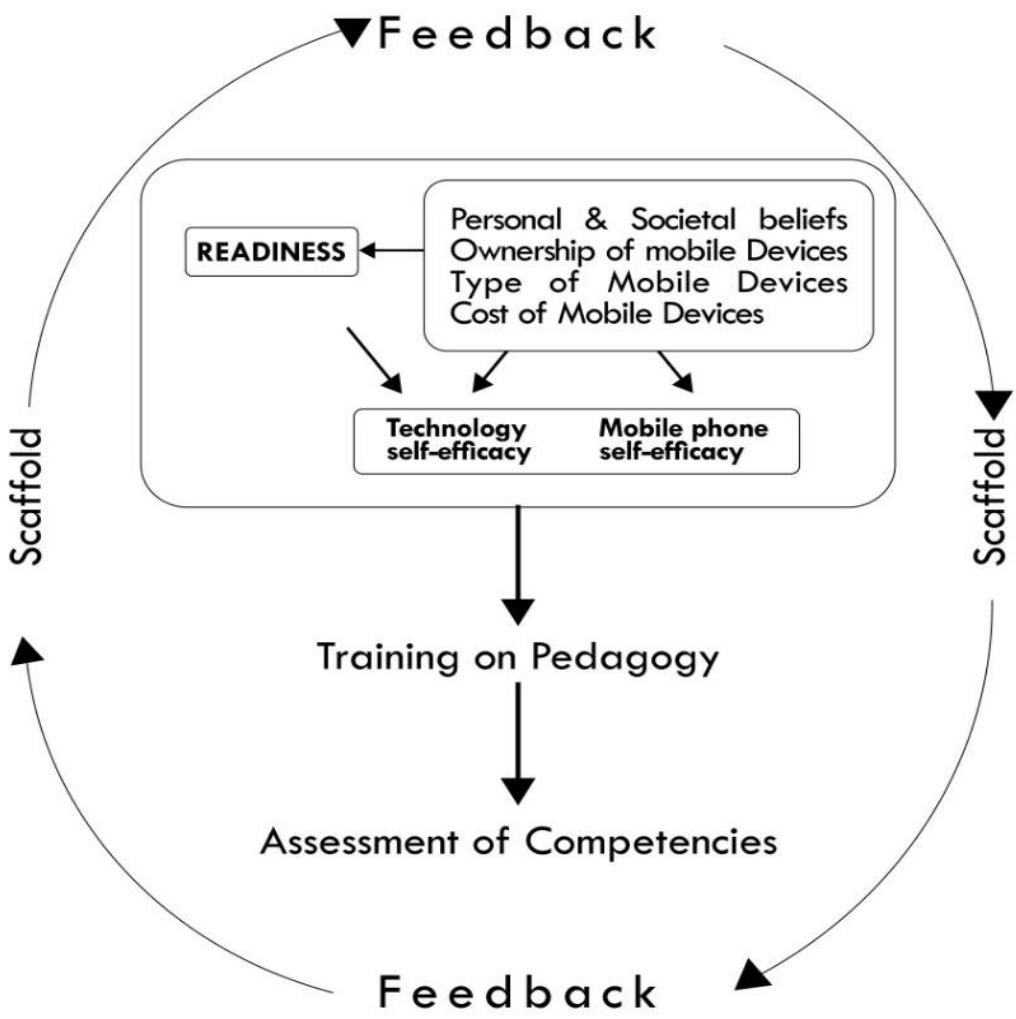

Figure1: Variables interactions

The findings reveal that teachers in Sub Sahara Africa have high level of readiness to use mobile learning for instructional delivery. In other words, teachers acknowledged the capabilities of mobile technology in enriching traditional classroom setting and therefore, ready to embrace it in engendering effective students' participation in instructional process. This could not be unconnected with the fact that mobile technology offers ubiquitous wireless devices that could enhance capabilities of students and educators in effective decision-making process. Technology has pervaded every aspect of our national life with increasing influence on the modes of instructional delivery at all levels of education (Abimbade et al, 2017). However, accessibility to ICT facilities has remained daunting challenge, especially to the teachers in this part of the world, as many schools are inadequately furnished with modern technologies to facilitate instructional process.

Technology integration into the classroom involves a radical decision and determination to shift from the didactic ways of teaching to an engaging and participatory teaching style. Therefore, it is only logical for teachers in SSA to leverage the capabilities of a low-cost and user-friendly device like mobile technology, as this tool could be found in the pockets of many students. This corroborates Barkham (2012) who asserts that "it would not be a viable option for schools that cannot afford sophisticated ICT facilities to ignore powerful gadgets like mobile phones that are available in every student's pocket." The study carried out by Kam et al., (2009) reveal that mobile phones have been acknowledged, by teachers and other educational stakeholders, as appropriate instructional devices for classroom activities especially in the developing countries where cell phones remain the only computing technology they have ready access to. This makes mobile phone a potential alternative for computer-related learning at all levels of education.

In the same vein, the analysis shows that Personal \& Societal beliefs, Ownership of devices, Cost of devices and Type of devices all contribute to the prediction of teacher's readiness towards uptake of mobile devices for instruction. This could be due to the centrality of these factors to technology use at all levels of education. The ownership and cost of devices are interrelated and strategic to the teachers' uptake of mobiles to facilitate teachinglearning process. It should be noted that teachers' readiness to integrate technology to classroom activities is partly a function of accessibility, ownership and cost of such instructional tools. Teachers are more likely to adopt and 
integrate instructional tools that are user-friendly, readily available and cost effective to ensure sustainability of technology use in the education system. It is known that teacher beliefs affect teachers' identities and teaching implementations at all levels of education (Sandretto, \& Heath, 2002; Hermans et al, 2008). Papanastasiou \& Angeli (2008) reported that failed ICT integration attempts did not take teachers' beliefs, attitudes, and skills into consideration. Gonca (2015) concludes that a statistically significant difference was also found in the mobile devices-related beliefs of the teachers that use the Internet to follow social media, and those that do not use the social media. It was determined that the differences in teachers' purposes for using Internet are related to their beliefs concerning mobile devices. Apparently, knowing teachers' beliefs and examining the variables that affect these beliefs would have an impact on teachers' readiness to use these technologies in the classroom for learning purposes. If a digital tool is cost is effective, such that many teachers can claim ownership of the technological device, then, it appeals to teachers' sense of readiness and they would be prepared to integrate it for classroom activities (Abimbade et al. 2019). This could be responsible for a positive relationship among Personal \& Societal beliefs, Ownership of devices, Cost of devices and Type of devices and teacher's readiness towards uptake of mobile devices for instruction.

Also, the findings reveal that teachers in Sub Sahara Africa possess the required skills and competences to integrate mobile learning to facilitate instructional process. This emphasizes the strategic position that training occupies in preparing prospective and in-service teachers for the task of integrating technological tools in classroom activities. The teacher's experience and exposure during training would have place him/her on a sound technologically sound pedestal to appreciate the enormous affordances provided by technological devices in facilitating learning. This could have led to positive attitude and readiness to integrating mobile technology into classroom instruction. In a study carried out by Adedoja and Abimbade (2013), the influence of the Mobile learning training on Technology/Mobile Phone Self-efficacies was explored. The results indicated that the pre-service social studies teachers have high Technology/Mobile Phone Self-efficacies after exposure to the training.

This is in line with Moore-Hayes (2011) assertion that teachers who feel that they have not been effectively trained on how to use technology to facilitate instructional process would probably have low technology selfefficacy. According to Levin \& Wadmany (2008), teachers that participate in training and 'ongoing' scaffolding have considerable higher self-efficacy to integrate technology and use technology for instruction than those who do not participated in training. It is important to note that integrating mobile technology to teaching-learning process requires systematic and well-coordinated procedure to seamlessly engage students in classroom activities. Although mobile phones are ubiquitous, user-friendly and cost effective, teachers need to galvanise these affordances to ensure that students use these devices for instructional purposes. Therefore, training teachers on the pedagogical use of mobile phones in classroom setting remains crucial for teachers at all levels of education.

\section{References}

Abimbade, O., Adedoja, G. O., Fakayode, B \& Bello, L. (2019). Impact of mobile - based mentoring, socio economic background and religion on girls' attitude and belief towards antisocial behaviour (ASB). British Journal of Educational Technology (BJET). Volume 50, Issue 2. https://doi.org/10.1111/bjet.12719

Abimbade, O., Akinyemi, A., Bello, L., Mohammed, H. (2017). Comparative Effects of an Individualized Computer-Based Instruction and a Modified Conventional Strategy on Students' Academic Achievement in Organic Chemistry. Journal of Positive Psychology and Counseling. 1(2). Pp 1-19.

Adedoja G., and Abimbade O. (2016). Design and Development of Mobile Learning Lesson Plan (MLLP) Template: A Design Relevant to African Context. American Journal of Educational Research, vol. 4, no. 9. 658-662. doi: 10.12691/education-4-9-2.

Abimbade, O. A. (2015). Development of Mobile Learning Package and Training of Pre-Service Social Studies Teachers in Mobile Phones Usage as Teaching Support for Secondary Schools. Unpublished Ph.D. Thesis.

Adedoja G. O., and Abimbade O. A. (2015). Pre-Service Teachers' Ease of Use and Intention to Use Selected Elearning Technologies in Designing Instruction. American Journal of Educational Research. Vol. 3, No. 10, 2015, pp. 1320-1323.http://pubs.sciepub.com/education/3/10/18

Adedoja G. O., and Abimbade O. A. (2016). Influence of Mobile Learning Training on Pre-Service Social Studies Teachers' Technology and Mobile Phone Self-Efficacies. Journal of Education and Practice, Vol. 7, No. 2, p74-79. http://eric.ed.gov/?id=EJ1089740

Adedoja, G.O. and Abimbade, O.A. (2013): Social Studies Teachers' Intention to Use Mobile Phone as a Support and Tutorial Tool for Teaching. 8th Annual IST-Africa Conference, Nairobi, Kenya. Paul Cunningham and Miriam Cunningham (Eds). IIMC International Information Management Corporation.

Attewell, J., Savill-Smith, C., and Douch, R., (2009). The Impact of Mobile Learning: Examining what it means for Teaching and Learning. Published by LSN. www.lsnlearning.org.uk retrieved on 16-1-2014

Bandura, A. (1977). Self-efficacy: toward a unifying theory of behavioural change. Psychological Review, 84:191215. Michigan.

Barker, A., Krull, G., \& Brenda, M (2009). A Proposed Theoretical Model for M-Learning Adoption in Developing 
Countries," in mLearn 2005 - 4th World conference on mLearning Cape Town. https://www.researchgate.net/publication/228363539

Berking, P., \& Haag, J. (2015). A Reference Model for Designing Mobile Learning and Performance Support. Interservice/Industry Training, Simulation, and Education Conference (I/ITSEC) https://adlnet.gov/public/uploads/A_Reference_Model_for_Designing_Mobile_Learning_and_Performance _Support_Haag_Berking.pdf

Brown, T. (2005). Towards a Model for m-Learning in Africa. International Journal on ELearning; 4(3) 299315.https://search.proquest.com/openview/47a1540df96c85b41ff5906a1d74fe30/1?pqorigsite $=$ gscholar \&cbl $=27101$

Coley, R., Cradler, J., \& Engel P. (2007). Computers and classrooms: The status of technology in U.S. schools (Educational Testing Service Policy Information Report). Retrieved from $\mathrm{ftp}: / / \mathrm{ftp}$. ets.org/pub/res/compclss.pdf

Daggett, W. 2010). Preparing students for the technological future. International Centre for Leadership in Education http://www.leadered.com/pdf/Preparing\%20Students\%20for\%20Tech\%20Future\%20white\%20paper.pdf

Docebo, (2017). Embracing the Mobile Future: Aligning L\&D with the Rise of Entreprise Mobility in Corporate elearning. www.docebo.com https://www.docebo.com/2017/04/27/enterprise-mobility-strategy/

Donnell, B. (2015). Panasonic The classroom of the future is here today. Tech analysis research LL. Retrieved March 27, 2017 from http://info.panasonic.com/rs/400-JUK-127/

Education 2025, (2015). The classroom of the future. Retrieved March 27, 2017 from https://education2025.wikispaces.com/The+Classroom + of + the+Future

Ericsson, (2016). Sub-saharan Africa Ericsson Mobility report, Stockholm, Sweden. https://www.ericsson.com/assets/local/mobility-report/documents/2016/ericsson-mobility-report-november2016-rssa.pdf

Fulkrum, S. (2005). Reasons to create a virtual class. Current Tech Issues 3.9

GSM Association, (2016). The Mobile Economy Africa, Retrieved April 4, 2017 from www.gsmaintelligence.com/research/?file=3bc21 ea879a5b217b64d62fa24c55bdf\&download

GSMA, 2016. The Mobile Economy Sub-saharan Africa, 2015. The Walbrook Building, London, UK. www.gsmamobileeconomy.com. https:/www.gsma.com/mobileeconomy/

Hermans, R., van Braak, J., \& Van Keer, H. (2008). Development of the beliefs about primary education scale: Distinguishing a developmental and transmissive dimension. Teachers and Teaching Education, 24, 127-139.

Kane, R., Sandretto, S. and Heath, C. (2002) Telling Half the Story: A Critical Review of Research on the Teaching Beliefs and Practices of University Academics. Review of Educational Research, 72, 177-228. http://dx.doi.org/10.3102/00346543072002177

Keegan, D. (2016). The Incorporation of Mobile Learning into Mainstream Education and Training. https:/quality4digitallearning.org/wpcontent/uploads/2016/03/keegan1.pdf Mobile Learning: a Handbook for Educators and Trainers Ed Agnes Kukulska-Hulme and John Traxler

Lenhart, A. (2010). Cell phones and American adults: They make just as many calls, but text less often than teens. Pew Internet \& American Life Project. Retrieved from http://www.pewinternet.org/ /media//Files/Reports/2010/PIP_Adults_Cellphones_Report_2010.pdf

Levin, T., \& Wadmany, R. (2008). Teachers' Views on Factors Affecting Effective Integration of Information Technology in the Classroom: Developmental Scenery. Journal of Technology and Teacher Education $16.2: 233-263$

Markauskaite, L. (2007). Exploring the structure of trainee teachers' ICT literacy: The main components of and relationships between, general cognitive and technical capabilities. Educational Technology Research and Development 55(6). 547-572. http://dx.doi.org/10.1007/s11423-007-9043-8

McGrath, F. (2009). Interactive technology in Social Studies. In P. Shaver (Ed.), Handbook of research on Social Studies teaching and learning (pp. 513-522). New York: Macmillan Publishing Company.

Moore-Hayes, C. (2011). Technology Integration Preparedness and its Influence on Teacher-Efficacy. Canadian journal of learning and technology 37.3.

Motiwalla, L. F. (2007). Mobile learning: A framework and evaluation. Computer \& Education. (49) 3, 581-596. https://www.sciencedirect.com/science/article/pii/S0360131505001569

Noeth, M.B. and Volkov, L.O. (2004). Trends in Internet information behavior, 2000-2004. Journal of the American Society for Information Science and Technology. 59(11). 1743-1760.

Ojerinde, D. (2011). JAMB's Fresh Onslaught against Exam Malpractice. www.allafrica.com. Retrieved on 4 November, 2011.

Papanastasiou, E. C., \& Angeli, C. (2008). Evaluating the Use of ICT in Education: Psychometric Properties of the Survey of Factors Affecting Teachers Teaching with Technology (SFA-T3). Educational Technology \& Society $11(1), 69-86$. 
PEW Research Centre, (2016), Smartphone Ownership and Internet usage continues to climb in emerging economies. http://www.pewglobal.org/2016/02/22/smartphone-ownership-and-internet-usage-continues-toclimb-in-emerging-economies/

PEW Research Centre, 2015. Cellphone in Africa: Communication Lifeline Texting most common activity, but mobile money popular in several countries. http://www.pewglobal.org/2015/04/15/cell-phones-in-africacommunication-lifeline/

Rosen, L., Lim, A., Carrier, L., \& Cheever, N. (2011). An empirical examination of the educational impact of text message-induced task switching in the classroom: educational implications and strategies to enhance learning. (2011). Psicologia Educativa, 17(2), 163-177.

Shafika, D. (2012). Mobile learning for teachers in Africa and Middle East; exploring the potentials of mobile technologies to support teachers and improve practice. UNESCO working paper series on Mobile Learning

Siegle, D. (2010). Cyberbullying and sexting: Technology abuses of the 21st century. Gifted Child Today, 33(2), 14.

Wagner, E 2005. Enabling mobile learning. Educause 